\title{
Historical Tropical Cyclone Activity and Impacts in the Cook Islands ${ }^{1}$
}

\author{
Fes A. de Scally ${ }^{2}$
}

\begin{abstract}
Analysis of a recently completed database of 143 tropical cyclones in the Cook Islands revealed a minimum average frequency of 0.8 cyclones per cyclone season between 1820 and 2006, with a more-precise frequency of $1.8 \mathrm{cy}-$ clones per season with the beginning of satellite monitoring of cyclones in 1970. Since $1970,31 \%$ of cyclones have reached hurricane intensity. The Southern Cooks have been more than twice as frequently affected by cyclones as the Northern Cooks, with the island of Palmerston having the greatest number of encounters. Since $1820,96 \%$ of cyclones have occurred during the official November-April cyclone season, with February alone accounting for $29 \%$. Since 1970, 46\% of cyclones achieving hurricane status have occurred in February. Nevertheless, Cyclone Martin in October-November 1997 demonstrated the dangers of a cyclone occurring outside the official season. An increase in cyclone occurrences since the mid-1970s is probably attributable to satellite monitoring, but it is noteworthy that all six cyclones known for certain to have achieved major hurricane status have occurred since 2002. Since 1970, 56\% of cyclones have occurred during El Niño events, an increase of $15 \%$ from the 1870-1969 period. Since 1891, cyclones with moderate and major human impacts have occurred on average at least every 3.8 and $8.8 \mathrm{yr}$, respectively, with the Southern Cooks more than twice as frequently affected as the Northern Cooks. However, past cyclone disasters in the latter group suggest that risk to human life is greater there due to the potential for inundation of the atolls by storm surges. Half of cyclones with human impacts have occurred during El Niño events, with weak to moderate El Niños almost as important in this respect as strong El Niños. Only $13 \%$ of cyclone impacts have occurred during La Niña events.
\end{abstract}

Historical Records of natural hazard impacts are an important tool for disaster preparedness (Asian Development Bank 1991, Tobin and Montz 1997, Zillman 1999), especially because human memory is frequently much shorter than the recurrence interval of many hazard phenomena (Granger 1999). Without such records the impact of a natural

\footnotetext{
${ }^{1}$ Financial support for this research was provided by University of British Columbia Okanagan research grants. Manuscript accepted 8 October 2007.

${ }^{2}$ Associate Professor of Geography, I. K. Barber School of Arts and Sciences, University of British Columbia Okanagan, 3333 University Way, Kelowna, British Columbia, Canada V1V 1V7 (e-mail: fes.descally@ ubc.ca.).
}

Pacific Science (2008), vol. 62, no. 4:443-459

(C) 2008 by University of Hawai'i Press

All rights reserved hazard is extremely difficult to evaluate (Tobin and Montz 1997). Several printed reports and Internet databases catalog historical tropical cyclone (henceforth simply called cyclone) activity in the Southwest Pacific Ocean, providing details on meteorological parameters such as tracks, intensities, and wind speeds. However, only a few provide any details at all about the cyclones' impacts on the inhabitants and communities of this region's island nations. Even fewer provide any information at all about cyclones and their impacts in the Cook Islands specifically (Visher 1925, Visher and Hodge 1925, Kerr 1976, Basher et al. 1992). As a result, although historical studies of cyclone impacts have been undertaken in some Pacific nations (e.g., Shaw 1981, Spennemann 2004), no upto-date or even incomplete record of cyclone activity exists for the Cooks. Yet this small nation is regularly affected by these storms, 


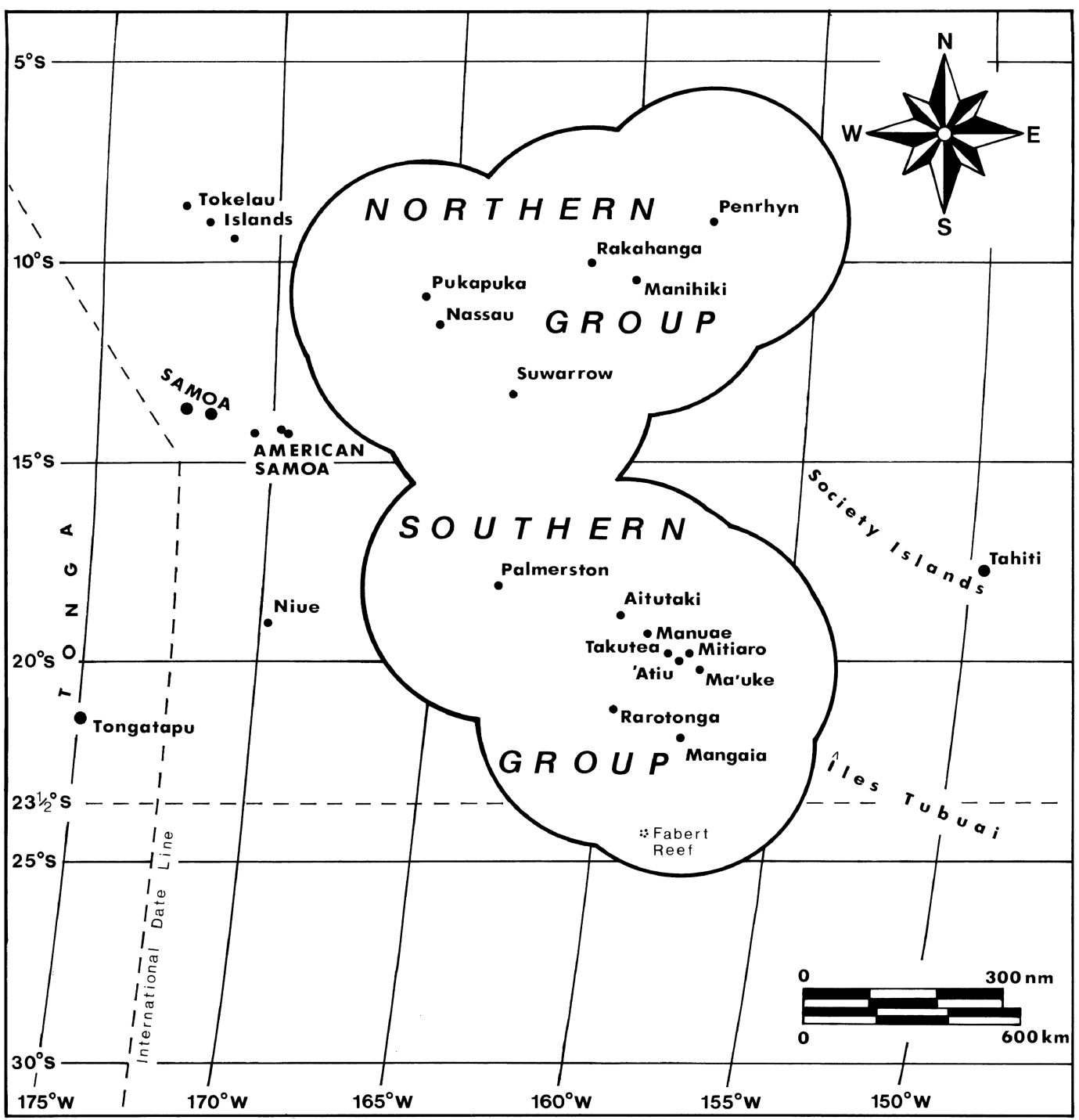

Figure 1. Cook Islands location map, showing the 200-nautical-mile (370-km) Exclusive Economic Zone (EEZ).

and after recent calamities such as deadly $\mathrm{Cy}-$ clone Martin in October-November 1997 and four destructive cyclones in FebruaryMarch 2005 there is a recognition that a historical database of cyclones and their impacts is urgently required. The purpose of this paper is to briefly describe the recent completion of such a database and then to provide some results from its analysis.
The Cook Islands consist of 15 small islands scattered over 2 million $\mathrm{km}^{2}$ of the Southwest Pacific (Figure 1). The Southern Cooks, officially called the Southern Group, consist of the high volcanic island of Rarotonga; almost-atoll of Aitutaki; makatea (upraised coral) islands of 'Atiu, Ma'uke, Mangaia, and Mitiaro; atolls of Palmerston and Manuae; and coral cay of Takutea. The 
Northern Cooks (Northern Group) islands are all atolls with the exception of Nassau, a coral cay. The climate of both groups is dominated by the extensive and persistent trade-wind zone of the South Pacific Ocean (Thompson 1986a,b). The position and intensity of the South Pacific Convergence Zone (SPCZ), an area of convergence between low-latitude easterly trade winds and the higher-latitude southeast trades, have a major influence on the weather including cyclone formation, as discussed later. The dry season occurs from May to October, and the wet season and large majority of cyclones occur from November to April. The role of the El Niño-Southern Oscillation (ENSO) phenomenon in cyclone occurrence is discussed later. About $90 \%$ of the Cook Islands' current population of 21,000 lives in the Southern Group, with Rarotonga containing about $70 \%$ of the total population. The islands of Manuae, Takutea, and Suwarrow are currently uninhabited.

\section{MATERIALS AND METHODS}

The analysis in this paper is based on a recently completed database of historical cyclone activity and its impacts in the Cook Islands (de Scally et al. 2006). This database was compiled from a wide variety of printed meteorological reports, Internet cyclone databases and reports, and nonmeteorological sources of information. The most important of the printed meteorological reports are those of Visher (1925), Visher and Hodge (1925), Hutchings (1953), Kerr (1976), Revell (1981), Basher et al. (1992), Thompson et al. (1992), and cyclone reports of the Fiji Meteorological Service. For more recent cyclone activity, important Internet sources are the databases of the U.S. Navy (2004), Joint Typhoon Warning Center (2005), Herold et al. (2006), and Bath and Deguara (2007), as well as the archived annual reports of the Joint Typhoon Warning Center. An enormous variety of nonmeteorological sources were vitally important for obtaining information on cyclone impacts (fatalities, injuries, damage to infrastructure and crops, and other eco- nomic and social impacts): they include such diverse material as memoirs of nineteenthcentury London Missionary Society priests (e.g., Williams 1841, Sunderland and Buzacott 1866, Gill 1894), annual reports of the Cook Islands Administration published in the Appendices to the Journals of the House of Representatives of New Zealand and dating back to 1891, periodicals such as Pacific Islands Monthly and Cook Islands News, and online reports of disaster-relief agencies such as the International Federation of Red Cross and Red Crescent Societies, United Nations Department of Humanitarian Affairs, and Office for Coordination of Humanitarian Affairs. The database itself contains a detailed description of the information sources used for creating it.

Two criteria were employed for including cyclones in the database (de Scally et al. 2006). First, any mention of impacts in any of the islands of the Southern and Northern Groups (Figure 1) warranted that cyclone's inclusion in the database. This ensured the inclusion of damaging cyclones even if they did not meet the second criterion. Because the intention was also to include cyclones that passed close to the Cook Islands whether or not they had any impact, a second criterion was employed: any cyclone spending a portion of its life, no matter how briefly, inside the Cook Islands' Exclusive Economic Zone (EEZ) was included in the database (Figure 1). For simplicity the 200-nautical-mile (370$\mathrm{km}) \mathrm{EEZ}$ circles in Figure 1 ignore the EEZ of adjoining jurisdictions and therefore probably differ slightly from the official boundary. Nevertheless this provided an objective criterion by which to include cyclones in the database. A tropical cyclone for this purpose was defined as any nonfrontal synoptic-scale, cyclonic system of tropical origin possessing sustained winds of at least gale force or 62 $\mathrm{km} / \mathrm{hr}$ (Holland 1983, Henderson-Sellers et al. 1998) (Table 1). If it could be determined from best-track data that a cyclone's sustained winds did not achieve gale intensity while inside the EEZ, it was excluded from the database.

An in-depth discussion of the quality of 
TABLE 1

Classification of Tropical Cyclone Intensity (from Revell 1981)

\begin{tabular}{llll}
\hline \hline & \multicolumn{3}{c}{$\begin{array}{c}\text { Equivalent Maximum } \\
\text { Sustained Winds }\end{array}$} \\
\cline { 2 - 4 } $\begin{array}{l}\text { Beaufort Scale } \\
\text { Description }\end{array}$ & $\mathrm{knots}$ & $\mathrm{m} / \mathrm{sec}$ & $\mathrm{km} / \mathrm{hr}$ \\
\hline Below gale ( $\leq$ force 7) & $<34$ & $<17.2$ & $<62$ \\
Gale (force 8 or 9) & $34-47$ & $17.2-24.4$ & $62-88$ \\
Storm (force 10 or 11) & $48-63$ & $24.5-32.6$ & $89-117$ \\
Hurricane (force 12) & $>63$ & $>32.6$ & $>117$ \\
Major hurricane & $>90$ & $>46.3$ & $>167$ \\
\hline
\end{tabular}

${ }^{a}$ Systems with winds below gale force are not considered tropical cyclones.

the resulting record is contained within the database (de Scally et al. 2006). Worth noting here is the changing quality of cyclone data in the historical sources described earlier, including the differing criteria employed for identifying cyclones, especially in the early records. More important, the availability of limited satellite imagery in the South Pacific before 1980 and the nonavailability of imagery before 1970 means that the real number of cyclones before the satellite era may never be known (Steve Ready, quoted by Maunder 1995). In the database, the first recorded use of satellite imagery to identify and locate cyclones occurs in December 1967, and so it is assumed that after 1970 all cyclones have been recorded. The lack of satellite data before about 1970 also makes the classification of cyclone intensity extremely difficult. The lack of satellite observations can be partly circumvented in populated archipelagos by the availability of ground-based observations, allowing at least important cyclones to be recorded. Between 1891 and 1970, detailed reporting by the Cook Islands Administration and periodicals such as Pacific Islands Monthly and Cook Islands News ensures that most or all important or damaging cyclones are included in the database. In contrast, the cyclone record before 1891 is patchy.

\section{RESULTS}

The cyclone database contains 166 entries dating back to approximately 1600. Of this total, 143 are classified as tropical cyclones with a high degree of certainty; the remaining 23 are excluded from the analysis in this paper. The potential value of Cook Islanders' oral histories for gaining insights into cyclones before Europeans' arrival is suggested by three events in ca. 1590, 1665, and 1785 as written down by Gill (1894) and Beaglehole and Beaglehole (1938). The ca. 1590 cyclone produced a storm surge that killed almost all of the estimated 1,000 to 2,000 inhabitants of Pukapuka (Beaglehole and Beaglehole 1938). However, given the difficulty of separating myth from fact in such oral histories, these cyclones are also excluded from the analysis. Cyclone entries subsequent to these, which began in ca. 1820, include descriptions of several parameters. For many nineteenth-century cyclones this includes only the date, a subjective classification of intensity, and brief descriptions of the origin and track, although some also have information available on the specific islands affected and the impacts. The impacts of some major cyclones, including ones that struck Rarotonga in December 1831 and March 1846, are described in great detail. For more recent cyclones the parameters for which information is available usually include the date, cyclone name and identification numbers, intensity category (Table 1), precise origin and track, maximum sustained wind speed and occasionally gust speed, minimum barometric pressure, islands affected, impacts, and other miscellaneous information. The analysis reported in this paper focuses on spatial and temporal patterns of cyclone activity, and cyclone intensity and impacts.

With at least 143 cyclones having affected the Cook Islands between 1820 and 2006, a minimum average frequency of 0.8 cyclones per cyclone season is derived, corresponding to a recurrence interval of $1.3 \mathrm{yr}$ if recurrence interval is taken as the reciprocal of frequency (Table 2). Twenty-one percent of these are known with a high degree of certainty to have achieved hurricane or major hurricane status (Table 1), probably an underestimate given the lack of satellite monitoring before 1970 . In the satellite era after 197065 cyclones have affected the Cooks, 
TABLE 2

Cyclone Occurrences for the Country as a Whole and by Group

\begin{tabular}{|c|c|c|c|c|c|c|}
\hline \multirow[b]{2}{*}{ Area } & \multicolumn{3}{|c|}{$1820-2006$} & \multicolumn{3}{|c|}{ 1970-2006 } \\
\hline & $\begin{array}{c}\text { Total } \\
\text { Cyclones }\end{array}$ & $\begin{array}{c}\text { Average Cyclones } \\
\text { per Season }\end{array}$ & R.I. ${ }^{a}$ & $\begin{array}{c}\text { Total } \\
\text { Cyclones }\end{array}$ & $\begin{array}{l}\text { Average Cyclones } \\
\text { per Season }\end{array}$ & R.I. ${ }^{a}$ \\
\hline Cook Islands & 143 & 0.8 & 1.3 & 65 & 1.8 & 0.6 \\
\hline Southern Group ${ }^{b}$ & 119 & 0.6 & 1.6 & 58 & 1.6 & 0.6 \\
\hline Northern Group ${ }^{b}$ & 42 & 0.2 & 4.4 & 25 & 0.7 & 1.4 \\
\hline Group unknown & 6 & - & - & 0 & - & - \\
\hline Palmerston & 53 & 0.3 & 3.5 & 25 & 0.7 & 1.4 \\
\hline
\end{tabular}

${ }^{a}$ Recurrence interval (yr).

${ }^{b}$ Each group's tally includes cyclones that affected both groups.

giving a considerably higher and more precise average frequency of 1.8 cyclones per season and corresponding recurrence interval of 0.6 yr (Table 2). This includes 20 hurricanes or major hurricanes (31\% of all cyclones), giving an average frequency of 0.6 per season (recurrence interval $=1.8 \mathrm{yr}$ ) during the 1970 2006 period for cyclones achieving these intensities.

Figure 2 shows 104 cyclones since 1820 for which sufficient track information is available for plotting. The dominant northwest to southeast track pattern just to the south of the Southern Group islands is apparent. The majority of cyclones affecting the Cook Islands have originated in the region of Samoa, northern Tonga, and Wallis and Futuna, although many others have originated within the Northern Group and subsequently tracked roughly southwest. Occasionally cyclones have tracked to the Cooks from as far west as the Solomon Islands.

Table 2 shows cyclone activity by group based on documented impacts on individual islands and, in some cases, effects inferred from the proximity of the cyclone track to specific islands. The Northern Group tally does not include several tropical disturbances and depressions that originated within that group's EEZ (Figure 1) but failed to achieve tropical cyclone status until after they had tracked into the Southern Group's EEZ. Between 1820 and 2006 at least 119 cyclones affected the Southern Group, giving a minimum average frequency of 0.6 cyclones per season (recurrence interval $=1.6 \mathrm{yr}$ ). Only 42 cyclones are recorded to have affected the Northern Group during that period, giving a minimum average frequency of 0.2 cyclones per season (recurrence interval $=4.4 \mathrm{yr}$ ). Since 1970, 58 cyclones have occurred in the Southern Group and 25 in the Northern Group, giving average frequencies of 1.6 (recurrence interval $=0.6 \mathrm{yr}$ ) and 0.7 (recurrence interval $=1.4 \mathrm{yr}$ ) per season, respectively (Table 2). Palmerston (Figure 1) is the island most frequently affected by cyclone activity, as shown by the statistic in Table 2 that is based on both reported effects and effects inferred from the proximity of cyclone tracks to Palmerston (Figure 2).

Figure 3 shows the monthly distribution of cyclone activity during the 1820-2006 period, with five of the 143 cyclones excluded because the month of occurrence is unknown. In cases where a cyclone tracked from the end of one month into the next, it is counted as an occurrence in both months. The exception to this rule is if the first day of cyclone occurrence was on the last day of a month, or the last day of occurrence was on the first day of a month: in this case the cyclone is counted only in the other month, following the convention of Kerr (1976), Revell (1981), and Thompson et al. (1992). Ninety-six percent of all cyclones have occurred during the official Southern Hemisphere tropical cyclone season from 1 November to 30 April, with February the single most active month with $29 \%$ of all cyclone occurrences (Figure 


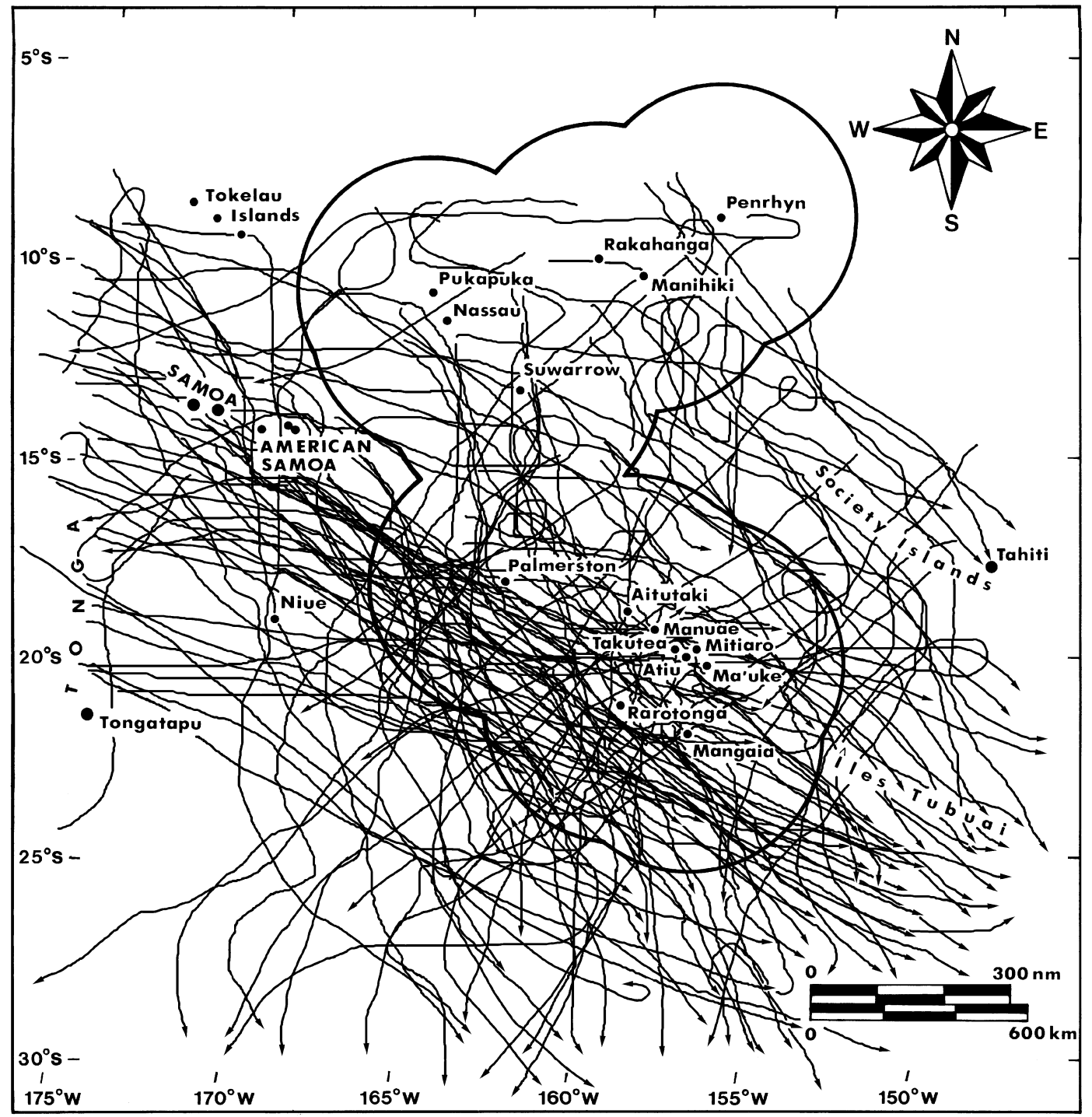

Figure 2. Generalized tracks of 104 cyclones in the Cook Islands, 1820-2006. The origin of cyclones tracking from west of $175^{\circ} \mathrm{W}$ longitude is not shown, and many cyclones tracked east or south out of the map area before decaying or undergoing extratropical transition.

3). Of the $4 \%$ of cyclones outside the official season, the greatest number have occurred in October and May, with two cyclones in total recorded in each. The 34 cyclones that could be unambiguously categorized as hurricanes or major hurricanes on the basis of maximum sustained winds (Table 1) all occurred during the December-April period. February is again the most active month for cyclones in these categories, with just over $38 \%$ of all occurrences (Figure 3). Figure 3 also shows the monthly distribution of the 65 cyclones and 20 hurricanes/major hurricanes that have occurred since 1970. Although the percentages 


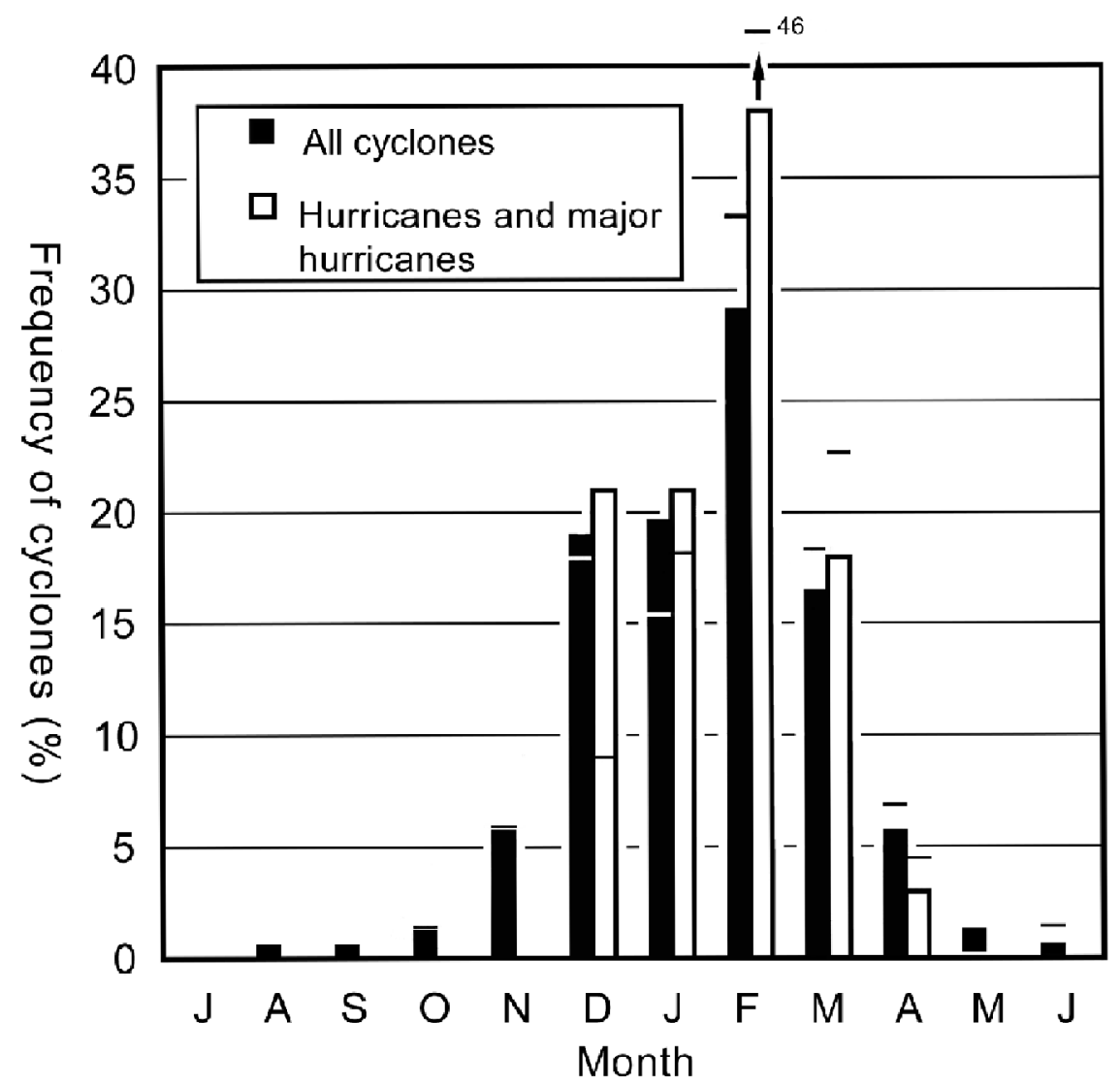

Figure 3. Monthly distribution of cyclones in the Cook Islands, 1820-2006. The criteria for the hurricane and major hurricane categories are shown in Table 1. Short horizontal lines inside or above the bars show 1970-2006 percentages.

of cyclones falling inside and outside the official tropical cyclone season are almost unchanged from the whole 1820-2006 period (97 and 3, respectively), December-January show a slightly smaller proportion of cyclones and hurricanes/major hurricanes, and February-April show a slightly larger proportion. February accounts for $33 \%$ of all cyclones and $46 \%$ of hurricanes/major hurricanes since 1970; the latter figure is $8 \%$ higher than for the 1820-2006 period of record.

Figure 4 shows the annual number of cyclones for the 1820-2006 period. It must be emphasized again that the early record is incomplete, and only after the reporting of cy- clone impacts began in the annual reports of the Cook Islands Administration in 1891 and in Pacific Islands Montbly in 1930 does the record of important cyclones become reasonably complete. The record for more minor cyclones is probably not complete until the beginning of the satellite era, as discussed earlier. Figure 5 summarizes the frequency of seasonal cyclone numbers for the 1820 2006 and 1970-2006 periods. The disproportionately large number of cyclone seasons with one cyclone occurrence in the whole 1820-2006 record reflects to an unknown extent the early years when usually only landfalling cyclones could be observed. In contrast, the lower proportion of seasons with 


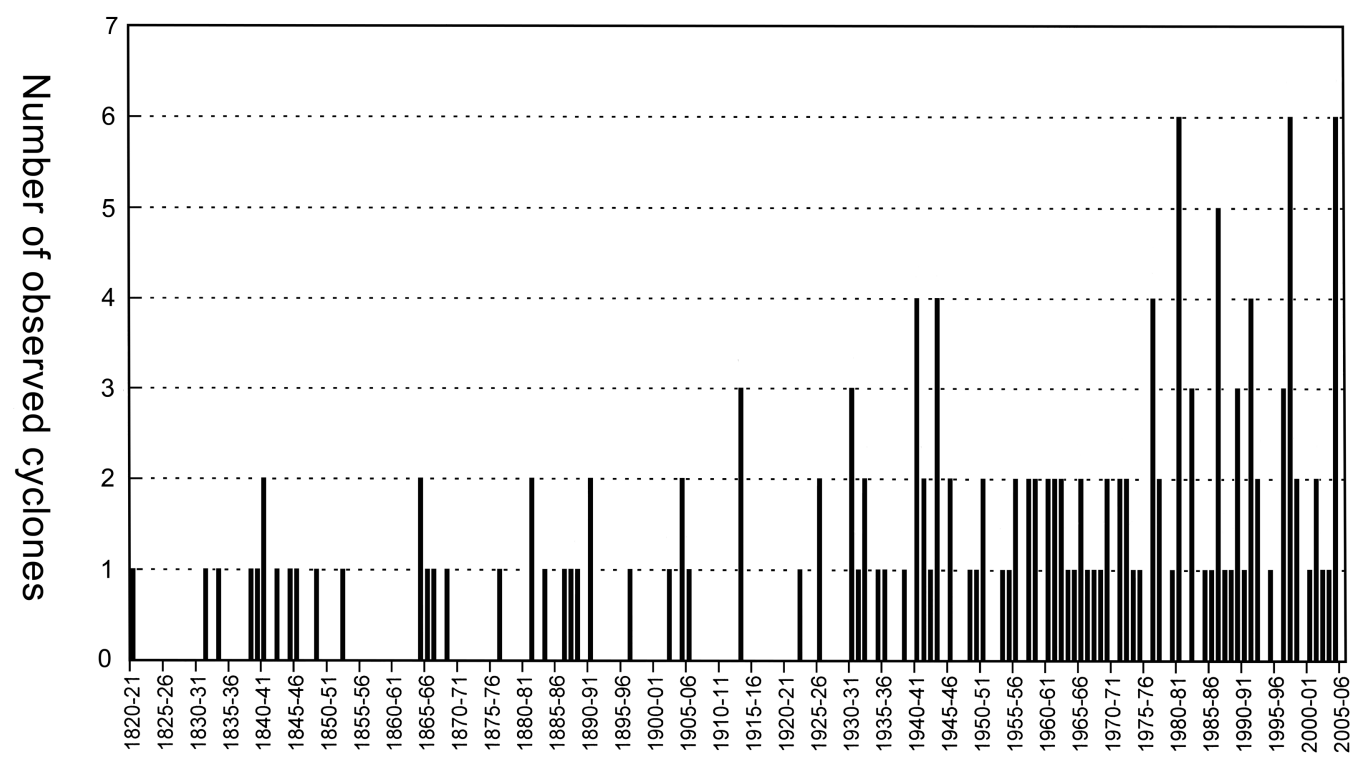

\section{Cyclone season}

Figure 4. Number of cyclones per season, 1820-2006.

one or two cyclones and correspondingly higher proportion with three or more cyclones since 1970 probably reflects the impact of satellite observation, when presumably all cyclones have been detected. Since 1970, only nine seasons have experienced no cyclone activity in the Cook Islands. The maximum number of cyclones in the Cooks' EEZ in one season (six) occurred in the 19801981, 1997-1998, and 2004-2005 seasons.

Table 3 shows El Niño-Southern Oscillation (ENSO) episodes since 1870 that have occurred during cyclone seasons with observed cyclones. El Niño and La Niña events are identified using the Niño3.4 sea-surface temperature (SST) index, which is the departure in monthly SST (relative to the 19611990 mean) averaged over the Niño3.4 region and available from the United Kingdom Met Office's Hadley Centre. An event is identified if the five-month moving average of the index exceeds $+0.4^{\circ} \mathrm{C}$ for El Niños and $-0.4^{\circ} \mathrm{C}$ for La Niñas for at least six consecutive months (Trenberth 1997, International Research Institute for Climate and Society 2006). This method is employed by
New Zealand's National Institute of Water and Atmospheric Research, among others, to identify El Niño and La Niña events in the Southwest Pacific (2007 unpublished report on ENSO event classification, National Climate Centre, Auckland). Table 4 shows that the proportion of total cyclones that have occurred during El Niño events has increased over time, with $56 \%$ of cyclones having occurred during El Niños since 1970 compared with only $41 \%$ for the 1870-1969 period. Table 5 shows that the relationship between the seasonal number of cyclones and $\mathrm{El}$ Niño strength is equivocal, with strong El Niños associated with slightly more cyclones over the 1870-1969 period but slightly fewer cyclones since 1970 .

The association between La Niña events and cyclone occurrences is also shown in Tables 3 and 4 . Table 4 shows that the proportion of total cyclones that have occurred during La Niña events has decreased over time, dropping from $17 \%$ over the 1870 1969 period to $9 \%$ since 1970 . The proportion of cyclones that have occurred during neutral ENSO conditions has also decreased 


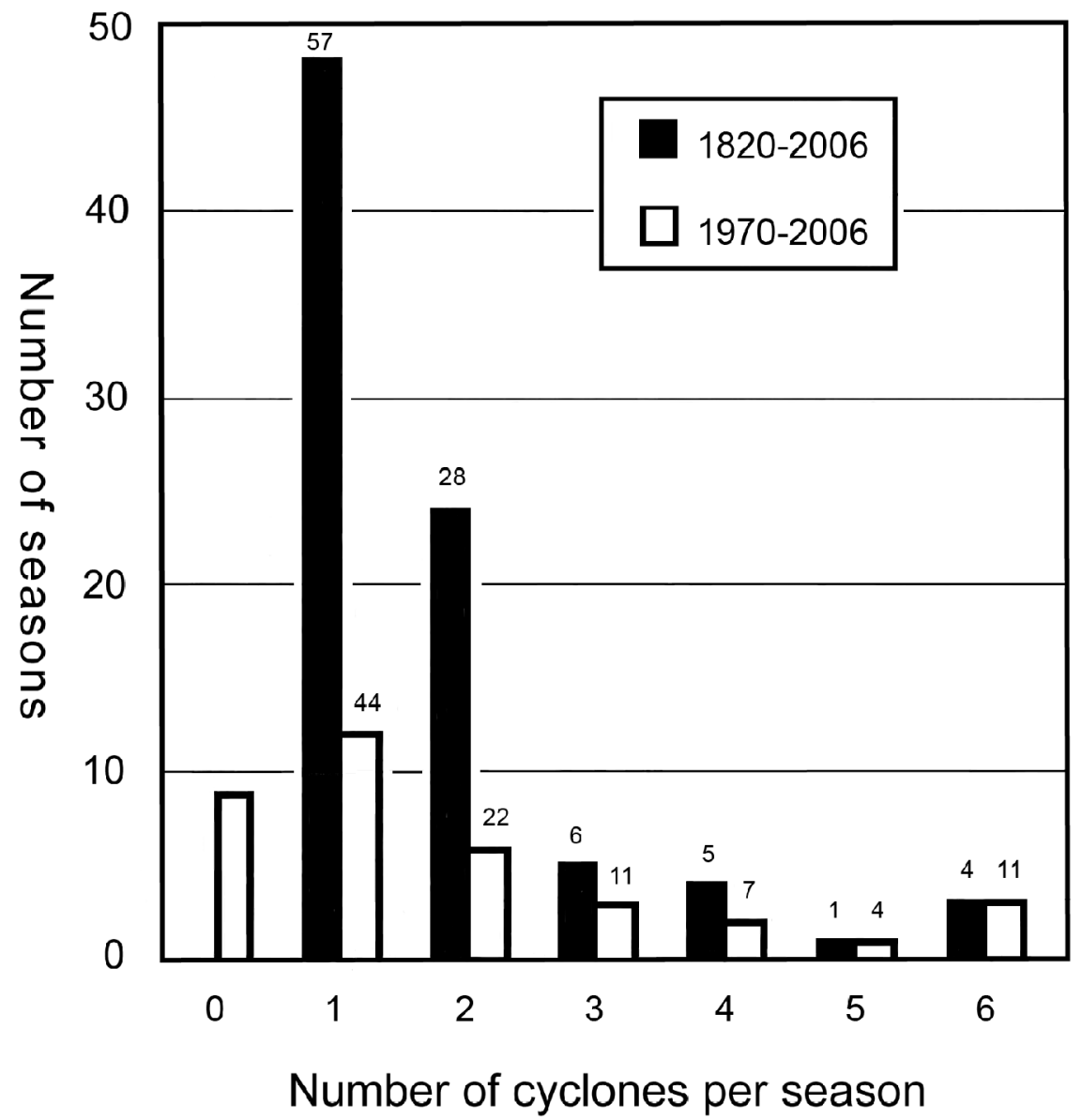

Figure 5. Frequency of seasonal cyclone totals. Numbers above the bars show the percentage of total seasons (seasons with no cyclones are excluded from the 1970-2006 calculations).

by $8 \%$. No attempt is made in Table 3 to identify El Niño or La Niña seasons with no cyclone activity, because before 1970 the cyclone record should be regarded as incomplete. After 1970, no El Niño events have coincided with a lack of cyclone activity in the Cook Islands, although El Niño conditions did develop at the end of the quiet 1993-1994 cyclone season.

Table 6 shows cyclone occurrences with minor, moderate, and major human impacts in the Cook Islands. "Minor" is defined as having resulted in no fatalities or injuries; minor damage to infrastructure or disruptions to power, telephone, and flights; or minor crop losses; and effects on only one or two islands. "Moderate" is defined as having resulted in no fatalities but possibly some minor injuries; or substantial but not widespread damage to infrastructure; or moderate to substantial crop losses; and effects on a small number of islands. "Major" is defined as having resulted in one or more fatalities or a substantial number of injuries; or substantial and widespread damage to or destruction of infrastructure and widespread crop losses; or a declaration of a state of emergency or request for international assistance. For cyclones where detailed information on impacts is unavailable, the damage classifications of Visher (1925), 
TABLE 3

El Niño-Southern Oscillation Events since 1870 in Tropical Cyclone Seasons with Observed Cyclone Activity; Events Are Defined by Sea-Surface

Temperature (SST) Anomalies in the Niño3.4 Region (See Text)

\begin{tabular}{|c|c|c|}
\hline $\begin{array}{l}\text { Event } \\
\text { Type }\end{array}$ & $\begin{array}{l}\text { Cyclone } \\
\text { Season }\end{array}$ & $\begin{array}{l}\text { SST Anomaly in } \\
\text { Month of Cyclone } \\
\text { Occurrence (Average } \\
\text { if }>1 \text { Month) }\left({ }^{\circ} \mathrm{C}\right)\end{array}$ \\
\hline El Niño & $\begin{array}{l}1876-1877 \\
1888-1889 \\
1896-1897 \\
1902-1903 \\
1904-1905 \\
1905-1906 \\
1913-1914 \\
1925-1926 \\
1930-1931 \\
1940-1941 \\
1941-1942 \\
1957-1958 \\
1963-1964 \\
1965-1966 \\
1969-1970 \\
1972-1973 \\
1976-1977 \\
1977-1978 \\
1982-1983 \\
1986-1987 \\
1987-1988 \\
1991-1992 \\
1994-1995 \\
1997-1998 \\
2002-2003 \\
2004-2005\end{array}$ & $\begin{array}{l}+0.49 \\
+1.51^{a} \\
+1.18^{a} \\
+0.53^{a} \\
+0.91 \\
+0.85 \\
+0.84 \\
+1.47^{a} \\
+1.46^{a} \\
+1.46^{a} \\
+0.90 \\
+1.52^{a} \\
+0.83 \\
+1.04^{a} \\
+0.38 \\
+1.40^{a} \\
+0.39 \\
+0.54 \\
+2.16^{a} \\
+1.18^{a} \\
+0.40 \\
+1.66^{a} \\
+1.19^{a} \\
+2.04^{a} \\
+0.80^{a} \\
+0.35\end{array}$ \\
\hline La Niña & $\begin{array}{l}1886-1887 \\
1890-1891 \\
1938-1939 \\
1942-1943 \\
1949-1950 \\
1950-1951 \\
1954-1955 \\
1955-1956 \\
1964-1965 \\
1973-1974 \\
1984-1985 \\
1988-1989 \\
1998-1999 \\
2000-2001\end{array}$ & $\begin{array}{l}-1.01 \\
-0.84 \\
-0.79 \\
-0.99 \\
-1.48 \\
-0.79 \\
-0.59 \\
-1.16 \\
-1.05 \\
-0.83 \\
-0.82 \\
-1.33 \\
-1.09 \\
-0.58\end{array}$ \\
\hline
\end{tabular}

${ }^{a}$ Strong El Niño event as defined by the 5 -month running mean of SST anomalies exceeding $+1.00^{\circ} \mathrm{C}$ for three consecutive months.
TABLE 4

Cyclone Occurrences during El Niño, La Niña, and Neutral ENSO Conditions as Defined by SST Anomalies in the Niño3.4 Region (See Text)

\begin{tabular}{lcc}
\hline \hline & \multicolumn{2}{c}{$\begin{array}{c}\text { No. of Cyclone } \\
\text { Occurrences (\%) }\end{array}$} \\
\cline { 2 - 3 } & $1870-1969$ & $1970-2006$ \\
\hline El Niño events & $28(41)$ & $36(56)$ \\
Neutral conditions & $29(42)$ & $22(34)$ \\
La Niña events & $12(17)$ & $6(9)$ \\
Total number of cyclones & 69 & 64 \\
\hline
\end{tabular}

TABLE 5

Cyclone Occurrences during Weak to Moderate and Strong El Niño Events

\begin{tabular}{|c|c|c|c|}
\hline & $\begin{array}{l}\text { No. of } \\
\text { Seasons }\end{array}$ & $\begin{array}{c}\text { Total } \\
\text { Cyclones }\end{array}$ & $\begin{array}{c}\text { Average } \\
\text { Cyclones } \\
\text { per Season }\end{array}$ \\
\hline \multicolumn{4}{|l|}{$1870-1969$} \\
\hline All El Niños & 15 & 28 & 1.9 \\
\hline $\begin{array}{l}\text { Weak to moderate } \\
\text { El Niños }\end{array}$ & 7 & 12 & 1.7 \\
\hline Strong El Niños ${ }^{a}$ & 8 & 16 & 2.0 \\
\hline \multicolumn{4}{|l|}{$1970-2006$} \\
\hline All El Niños & 12 & 36 & 3.0 \\
\hline $\begin{array}{l}\text { Weak to moderate } \\
\text { El Niños }\end{array}$ & 4 & 13 & 3.3 \\
\hline Strong El Niños ${ }^{a}$ & 8 & 23 & 2.9 \\
\hline
\end{tabular}

${ }^{a}$ Five-month running mean of SST anomalies for three consecutive months: weak to moderate $\left\langle+1.00^{\circ} \mathrm{C}\right.$; strong $>$ $+1.00^{\circ} \mathrm{C}$.

TABLE 6

Number of Cyclones with Observed or Inferred Human Impacts

\begin{tabular}{|c|c|c|c|c|}
\hline \multirow[b]{2}{*}{$\begin{array}{l}\text { Type of } \\
\text { Impact }\end{array}$} & \multirow[b]{2}{*}{$\frac{1820-2006}{\begin{array}{c}\text { No. of } \\
\text { Cyclones }\end{array}}$} & \multicolumn{3}{|c|}{ 1891-2006 } \\
\hline & & $\begin{array}{c}\text { No. of } \\
\text { Cyclones }\end{array}$ & $\begin{array}{c}\text { Average } \\
\text { Cyclones } \\
\text { per Season }\end{array}$ & $\begin{array}{l}\text { Recurrence } \\
\text { Interval (yr) }\end{array}$ \\
\hline Minor & $38\left(33^{a}\right)$ & $35\left(33^{a}\right)$ & $0.3\left(0.6^{b}\right)$ & $3.3\left(1.7^{b}\right)$ \\
\hline Moderate & 32 & 30 & 0.3 & 3.8 \\
\hline Major & 21 & 13 & 0.1 & 8.8 \\
\hline
\end{tabular}

${ }^{a}$ Additional cyclones with inferred minor impacts (see text).

${ }^{b}$ Includes cyclones with inferred minor impacts. 
Kerr (1976), and Basher et al. (1992) are employed. During the 1820-2006 period $91 \mathrm{cy}-$ clones had an impact in the Cook Islands (Table 6). A further 33 cyclones are inferred to have resulted in minor impacts based on the proximity of their tracks to inhabited islands, because such minor effects frequently went unreported. Taking the 1891-2006 period when much more detailed records of cyclone impacts are available, an average of at least 0.3 cyclones per season (recurrence interval $=3.3 \mathrm{yr}$ ) have had minor impacts, 0.6 cyclones per season (recurrence interval $=1.7 \mathrm{yr}$ ) if those with inferred minor impacts are included (Table 6). On average at least 0.3 (recurrence interval $=3.8 \mathrm{yr}$ ) and 0.1 (recurrence interval $=8.8$ yr) cyclones per season have created moderate and major impacts, respectively (Table 6). Between 1820 and 1890, 10 cyclones with moderate or major impacts were recorded in the Southern Group but none in the Northern Group. This discrepancy may reflect the greater presence of Europeans in the Southern Group at that time, particularly London Missionary Society priests who made written observations of cyclones and their impacts (see, for example, Williams 1841, Sunderland and $\mathrm{Bu}-$ zacott 1866, Gill 1894). During the 18912006 period when more complete records of cyclone impacts are available for both groups, at least 19 cyclones with moderate impacts and six with major impacts were reported in the Southern Group, representing 58\% of all cyclones. In the Northern Group at least two cyclones with moderate impacts and two with major impacts (Cyclone Martin in 1997 and Cyclone Percy in 2005) were reported, representing $9 \%$ of all cyclones. Nine other cyclones with moderate impacts and five others with major impacts are reported to have affected both groups during the 18912006 period.

Table 7 shows the relationship between cyclone impacts and ENSO conditions. Since 1870 El Niño conditions have prevailed during 44, 63, and $47 \%$ of cyclones producing minor, moderate, and major impacts, respectively. Although strong El Niños were more common during cyclones with minor to moderate impacts compared with weak to moder-
TABLE 7

Occurrence of Cyclone Impacts during El Niño, La Niña, and Neutral ENSO Conditions, 1870-2006 (See Tables 3-5 for Criteria Employed for Defining ENSO Phases)

\begin{tabular}{|c|c|c|c|c|}
\hline \multirow[b]{2}{*}{$\begin{array}{l}\text { Type of } \\
\text { Impact }\end{array}$} & \multicolumn{4}{|c|}{ No. of Cyclone Impacts (\%) } \\
\hline & $\begin{array}{l}\text { Weak to } \\
\text { Moderate } \\
\text { El Niño }\end{array}$ & $\begin{array}{l}\text { Strong } \\
\text { El Niño }\end{array}$ & Neutral & La Niña \\
\hline Minor $^{a}$ & $12(17)$ & $19(27)$ & $27(39)$ & $12(17)$ \\
\hline Moderate & $7(23)$ & $12(40)$ & $10(33)$ & $1(3)$ \\
\hline Major & $4(27)$ & $3(20)$ & $6(40)$ & $2(13)$ \\
\hline
\end{tabular}

${ }^{a}$ Includes observed and inferred minor impacts (see text).

ate El Niños, weak to moderate El Niños were slightly more common during cyclones with major impacts. Table 7 also shows that $33-40 \%$ of cyclone impacts have occurred during neutral ENSO conditions, and only 3-17\% have occurred during La Niña events.

Table 8 lists all reported fatalities from cyclones in the Cook Islands, with the earliest reference being the destruction of almost the entire population of Pukapuka by a storm surge as described earlier. This record of fatalities is probably patchy until the detailed annual reporting by the Cook Islands Administration began in 1891.

\section{DISCUSSION}

The cyclone track pattern illustrated in Figure 2 reflects the broader geographical distribution of cyclones in the Southwest Pacific (Kerr 1976, Revell 1981, Thompson et al. 1992). Specifically, the dominant northwest to southeast pattern of cyclone tracks just to the south of the Southern Group, as well as a secondary pattern of roughly southwesterly motion originating within the Northern Group agree closely with Kerr's (1976) detailed analysis of cyclones' directional movement in this region. The dominant northwest-southeast pattern results from the fact that the SPCZ is often situated over the Southern Group during the cyclone season (Thompson 1986a,b, Graham et al. 1989, Sturman and McGowan 1999), with cyclones 
TABLE 8

Cyclones with Reported Fatalities

\begin{tabular}{|c|c|c|}
\hline Cyclone & Island & No. of Fatalities \\
\hline ca. 1590 & Pukapuka & Est. $1,000-2,000$ \\
\hline December 1831 & Rarotonga & $\begin{array}{l}\text { "Hundreds" from ensuing starvation, } \\
\text { with almost } 5,000 \text { more by } 1847 \text { from } \\
\text { disease due to food deprivation }\end{array}$ \\
\hline December 1842 & Mangaia & 1 (on ship) \\
\hline March 1866 & Mangaia & "Many deaths" from ensuing starvation \\
\hline March-April 1869 & Mangaia & Est. 11 (on ship) \\
\hline ca. 1872 & Mitiaro & 2 \\
\hline December 1883 & Rarotonga & 7 (on three ships) \\
\hline November 1890 & Aitutaki & 14 (on ship and two canoes) \\
\hline January 1905 & $\begin{array}{l}\text { Between Ma'uke } \\
\text { and 'Atiu }\end{array}$ & 1 (on ship) \\
\hline January 1914 & Rakahanga & 1 \\
\hline March 1926 & Palmerston & 1 \\
\hline February 1935 & Rarotonga & $\begin{array}{l}1 \text { plus a "high number" of tuberculosis } \\
\text { fatalities by } 1937 \text { due to food deprivation }\end{array}$ \\
\hline March 1943 & Rarotonga? & 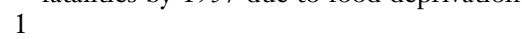 \\
\hline Tropical Cyclone Peni, February 1990 & Unknown & 1 \\
\hline Tropical Cyclone Martin, November 1997 & Manihiki & 19 \\
\hline
\end{tabular}

frequently developing in the zone of cyclonic wind shear that characterizes the SPCZ (Thompson 1986a,b). The lower frequency of cyclone activity in the Northern Group (Figure 2 and Table 2) results from the usual location of the SPCZ to the west and south of this group during the cyclone season.

The average seasonal frequencies of cyclones in the Southern and Northern Groups during the 1820-2006 period (0.6 and 0.2, respectively [Table 2]) are minimum estimates because the cyclone record on which they are based is incomplete for the nineteenth and early twentieth centuries. Furthermore, the historically larger population and longer European presence (and thus written records) in the Southern Group, especially Rarotonga, probably exaggerates the difference between the two groups. Thompson $(1986 a, b)$ reported identical average frequencies for the 1940-1984 period, which indicates that the records employed by him for the calculations are probably also incomplete; this is reinforced by the fact that during 1940-1984 he recorded only 11 cyclones for the Northern Group, but de Scally et al. (2006) recorded at least 22 cyclones. The average seasonal frequencies of cyclones in the two groups over the 1970-2006 period (1.6 and 0.7, respectively [Table 2]) are in good agreement with previously published estimates of 1.4 and 0.8 for the same period (Salinger et al. 2004). Given the more or less complete coverage of cyclone activity by weather satellites during this period, these figures are probably an accurate reflection of the true frequencies of cyclone occurrence (Thompson 1986b). The much higher frequency of cyclones in the Southern Group is related to the dominant northwest-southeast pattern of tracks just to the south of this group (Figure 2), as discussed earlier. The proximity of Palmerston to this track pattern is underscored by the fact that this island experienced more cyclones during the 1820-2006 period than all of the Northern Group combined, and an equal number since 1970 (Table 2).

The vast majority of historical cyclones (96-97\%) have occurred during the official November to April Southern Hemisphere cyclone season, reflecting the pattern elsewhere in the Australia-Southwest Pacific region (Henderson-Sellers et al. 1998). All hurricanes and major hurricanes have occurred during a narrower December-April period (Figure 3). However, complacency or a lack 
of preparedness outside the official cyclone season can have serious consequences, as demonstrated in Manihiki by Cyclone Martin in late October-early November 1997, when 19 people perished, 200 were injured and 700 more were affected, and $90 \%$ of properties were destroyed or damaged by a $10-\mathrm{m}$ storm surge and waves. The human toll in this disaster was attributed partly to the lack of timely warnings to the inhabitants (Fiji Meteorological Service 1999, Syme-Buchanan 1997). The monthly distribution of cyclones, including hurricanes and major hurricanes, appears to have shifted since 1970 (Figure 3 ), with slightly less activity in DecemberJanuary and slightly more in February-April compared with the complete 1820-2006 period. Although this shift is small overall, an $8 \%$ increase in hurricanes/major hurricanes in February is noteworthy.

Figures 4 and 5 show an apparent increase in the number of seasons with three or more cyclones since the mid-1970s, but this is almost certainly attributable to the beginning of satellite monitoring of cyclones. Other studies have found no discernible trend in the frequency of cyclones in the Southwest Pacific since 1970 (Henderson-Sellers et al. 1998, Emanuel 2005). What is not apparent in Figures 4 and 5 is the fact that all six cyclones known to have reached major hurricane status (Table 1) in the Cook Islands since 1970 have occurred in the last four seasons: Cyclone Dovi in 2002-2003, Cyclone Heta in 2003-2004 (which tracked just to the west of the Cooks' EEZ), and Cyclones Meena, Nancy, Olaf, and Percy in 20042005 (it is uncertain if Cyclone Ima in 19851986 became a major hurricane while inside the EEZ). On the Saffir-Simpson scale of intensity (National Oceanic and Atmospheric Administration 2007), Cyclones Dovi, Meena, and Nancy achieved a category four, and Cyclones Heta, Olaf, and Percy achieved a category five, the highest possible. This incidence of major hurricanes in recent years may reflect the fact that between 1975-1989 and 1990-2004, the number of category four and five hurricanes in several ocean basins increased by $120 \%$, and in the Southwest $\mathrm{Pa}$ cific the proportion of these making up the total number of cyclones increased from 12 to $28 \%$ (Webster et al. 2005). Emanuel (2005) also detected a marked increase in the destructiveness of cyclones in the North $\mathrm{Pa}$ cific since the mid-1970s. These increases, however, cannot be attributed to global warming without a longer record and a better understanding of the role of cyclones in the general circulation of the atmosphere and ocean (Webster et al. 2005). Nor can the effect of improved satellite monitoring and analysis in the last few years be discounted as a contributing factor (Diamond 2006).

Although some studies have failed to find a statistically significant association between the ENSO phenomenon and Southwest $\mathrm{Pa}$ cific cyclone activity (Ramage and Hori 1981, Hastings 1990), many have demonstrated a substantial eastward shift in Pacific cyclone activity during El Niño conditions as a result of changes in sea-surface temperature and tropospheric winds (Revell and Goulter 1986, Hastings 1990, Evans and Allan 1992, Basher and Zheng 1995, Terry et al. 2001, Elsner and Liu 2003). This eastward shift has the effect of extending cyclone activity in a wide band between $10^{\circ} \mathrm{S}$ and $25^{\circ} \mathrm{S}$ to as far east as the Cook Islands and French Polynesia, with the greatest incidence around the date line and east-southeast of Fiji (Basher and Zheng 1995). In contrast, during La Niña conditions little cyclone activity extends east of the date line (Basher and Zheng 1995). For both the Southern and Northern Groups of the Cook Islands, El Niño conditions are therefore accompanied by an increased probability of cyclones (Thompson 1986a,b). Salinger et al. (2004), for example, estimated increases in cyclone probability of $36-50 \%$ for the Southern Group and 13$25 \%$ for the Northern Group during even weak El Niño conditions, relative to the average probability for all years. This pattern is reflected in the much greater number of cyclones in our database that have occurred during El Niño conditions compared with neutral ENSO and La Niña conditions (Tables 3 and 4). Six of the eight seasons with four or more cyclones each have occurred during El Niño events; the exceptions are 1943-1944 with four cyclones and 1980- 
1981 with six cyclones, both during neutral ENSO conditions. Also of interest is the $15 \%$ increase in cyclone occurrences during El Niño conditions and corresponding 16\% decrease during neutral and La Niña conditions since 1970 compared with the 18701969 period (Table 4). This at least partly reflects the greater frequency of El Niño events since about 1990 (McGuire et al. 2002). It is surprising that the average seasonal number of cyclones is affected little by the strength of the El Niño events; in fact since 1970 the average is higher for weak to moderate $\mathrm{El}$ Niños than for strong ones (Table 5). This was dramatically illustrated by the modest El Niño conditions of 2004-2005 when a record six cyclones affected the Cook Islands. The results in Table 4 also support the observation by Thompson (1986b) and HendersonSellers et al. (1998) that cyclone-free seasons tend to coincide with La Niña conditions; only a small proportion of cyclone occurrences in the Cooks are associated with $\mathrm{La}$ Niña events, with this proportion having decreased from $17 \%$ in the $1870-1969$ period to $9 \%$ since 1970 . In contrast Hastings (1990) found that in five cyclone seasons with strong El Niño conditions and three with strong La Niña conditions, $36 \%$ of cyclones occurred during the latter. This may reflect the greater probability of cyclones off the east coast of Australia during La Niña conditions (McGuire et al. 2002).

The record of cyclone impacts since 1891 shows that, on average, the Cook Islands have suffered minor impacts about every $2 \mathrm{yr}$, moderate impacts about every $4 \mathrm{yr}$, and major impacts about every 9 yr (Table 6). These frequencies should be viewed as minima because it is not certain whether all cyclones with impacts are captured in the record. The statistics show a major difference between the Southern and Northern Groups in terms of important (moderate to major) impacts: during the 1891-2006 period, 58\% of cyclones with important impacts have struck the seven inhabited islands of the Southern Group, and only $9 \%$ of this kind of cyclone have struck the five inhabited islands of the Northern Group. In $33 \%$ of cases the cyclones resulted in substantial impacts in both groups. Therefore, notwithstanding some possible bias toward reported impacts in the Southern Group, it appears that this group is at more than twice the risk of significant cyclone impacts than the Northern Group. Given the definitions for moderate and major impacts employed in this paper, this difference in risk levels can be ascribed mostly to the substantially higher probability of cyclone occurrence in the Southern Group (Figure 2 and Table 2). In the Northern Group, Penrhyn Atoll is generally regarded as being outside the cyclone belt, but our database shows it to have been affected by three cyclones with important impacts and four to eight cyclones with minor impacts.

Table 7 shows that approximately half of cyclone impacts have occurred during El Niño events, roughly in proportion to the frequency of cyclones occurring during $\mathrm{El}$ Niños (Table 4). Strong El Niños are more closely associated with minor to moderate cyclone impacts, which is strange given the lack of any notable relationship between El Niño strength and cyclone frequency (Table 5). Major cyclone impacts have occurred more frequently during weak to moderate $\mathrm{El}$ Niños than during strong ones (Table 7). Only a very small proportion of cyclone impacts are associated with La Niña events (Table 7).

Table 8 shows that although Cyclone Martin in 1997 was the deadliest cyclone in the Cook Islands in over a century, calamities such as this pale into relative insignificance compared with historic death tolls such as recorded in Pukapuka in ca. 1590, Rarotonga in 1831, and Mangaia in 1866. Many of the fatalities in these historic disasters resulted from famine when food crops were destroyed and, after the arrival of Europeans early in the nineteenth century, also from illness due to decreased resistance to introduced diseases from hunger. With the notable exception of Cyclone Martin, few fatalities have occurred in modern cyclones due to improved warning systems, use of evacuation and cyclone shelters, and provision of relief supplies by sea and air. This trend toward reduced mortality mirrors that in developed countries such as 
the United States and Australia (HendersonSellers et al. 1998, Smith 2004). On the other hand, the monetary value of damage from cyclones in the Cook Islands appears to be escalating, mirroring another trend apparent along tropical coasts undergoing rapid development (Henderson-Sellers et al. 1998, Smith 2004). For example, damage estimates for recent major cyclones (unadjusted for inflation) include US \$20-40 million in Cyclone Sally (1986-1987), US \$8 million in Cyclone Martin (1997), and over US \$25 million in Cyclones Meena, Nancy, Olaf, and Percy (2005). Such losses can have a substantial impact on the Cook Islands' small economy: the damage from the 2005 cyclones, for example, represents at least $14 \%$ of the country's gross domestic product at the time.

With respect to future cyclones, Rarotonga appears to be most at risk of costly damage given the increase in tourism infrastructure along the shoreline, which is exposed to storm surges and high waves. Rarotonga also serves as the transportation, administrative, and commercial hub of the Cook Islands, with the result that impacts on these sectors there will have repercussions throughout the country. Despite its much smaller population, the Northern Group is probably most at risk of loss of life: as $\mathrm{Cy}-$ clone Martin in Manihiki, the ca. 1590 cyclone in Pukapuka, the February 1942 cyclone in Suwarrow, and others have demonstrated, a storm surge can raise sea level sufficiently to cause waves to wash completely over the low-lying atolls. Because evacuation of these remote atolls during the approach of a cyclone is not an option, reducing the inhabitants' vulnerability hinges on properly situated and constructed cyclone shelters and timely warnings. Palmerston in the Southern Group is probably the atoll most likely to be struck (Figure 2 and Table 2); fortunately its population numbers less than 100 . The outer islands of both groups are also substantially more vulnerable in terms of human livelihoods, because they are much slower to recover from a disaster in comparison with Rarotonga. This was illustrated by the slow, and to some extent still ongoing, recovery in
Pukapuka and Nassau after Cyclone Percy in 2005.

\section{ACKNOWLEDGMENTS}

The assistance of numerous agencies and individuals in the creation of the historical database (de Scally et al. 2006), and the ongoing assistance and support of Arona Ngari, Director of the Cook Islands Meteorological Service, are gratefully acknowledged. Jim Salinger from New Zealand's National Institute of Water and Atmospheric Research supplied valuable insights and data for defining El Niño-Southern Oscillation phases. The comments of two anonymous reviewers on an early version of this paper were very helpful. The work in this paper is dedicated to the memory of Patricia Numa of Upper Tupapa, Rarotonga, who provided the main motivation for this project.

\section{Literature Cited}

Asian Development Bank. 1991. Disaster mitigation in Asia and the Pacific. Asian Development Bank, Manila.

Basher, R., B. Collen, B. Fitzharris, J. Hay, B. Mullan, and J. Salinger. 1992. Preliminary studies of South Pacific climate change: Present climate change and its impacts, data resources, and scenario possibilities. New Zealand Meteorological Service and New Zealand Climate Change Program, Wellington.

Basher, R., and X. Zheng. 1995. Tropical cyclones in the Southwest Pacific: Spatial patterns and relationships to Southern Oscillation and sea surface temperature. J. Clim. 8:1249-1260.

Bath, M., and J. Deguara. 2007. Australia severe weather: Tropical cyclones. Australia Severe Weather Association, St. Ives (New South Wales), http://www .australiasevereweather.com/cyclones/ index.html.

Beaglehole, E., and P. Beaglehole. 1938. Ethnology of Pukapuka. Bernice P. Bishop Mus. Bull. 150. 
de Scally, F. A., G. V. Wood, L. K. Maguire, M.-A. Fournier-Beck, and D. Silcocks. 2006. A history of tropical cyclones and their impacts in the Cook Islands. Cook Islands Meteorological Service, Nikao (Rarotonga).

Diamond, H. J. 2006. Review of recent tropical cyclone climatological research. Island Clim. Update 72, http://www.niwa.cri.nz/ ncc/icu/2006-09/article.

Elsner, J. B., and K.-B. Liu. 2003. Examining the ENSO-typhoon hypothesis. Clim. Res. 25:43-54.

Emanuel, K. 2005. Increasing destructiveness of tropical cyclones over the past 30 years. Nature (Lond.) 436:686-688.

Evans, J. L., and R. J. Allan. 1992. El Niño/ Southern Oscillation modification to the structure of the monsoon and tropical cyclone activity in the Australian region. Int. J. Climatol. 12:611-623.

Fiji Meteorological Service. 1999. Tropical cyclone Martin, $31^{\text {st }}$ October-5 ${ }^{\text {th }}$ November 1997. Tropical Cyclone Report 97/2.

Gill, W. W. 1894 (reprinted 1995). From darkness to light in Polynesia. Institute of Pacific Studies, University of the South Pacific, Suva.

Graham, N. E., T. P. Barnett, R. M. Chervin, M. E. Schlesinger, and U. Schlese. 1989. Comparisons of GCM and observed surface wind fields over the tropical Indian and Pacific Oceans. J. Atmos. Sci. 46:760788.

Granger, K. 1999. An information infrastructure for disaster management in Pacific island countries. Australian Geological Survey Organization, Canberra, Record 1999/35.

Hastings, P. A. 1990. Southern Oscillation influences on tropical cyclone activity in the Australian/South-West Pacific region. Int. J. Climatol. 10:291-298.

Henderson-Sellers, A., H. Zhang, G. Berz, K. Emanuel, W. Gray, C. Landsea, G. Holland, J. Lighthill, S.-L. Shieh, P. Webster, and K. McGuffie. 1998. Tropical cyclones and global climate change: A post-IPCC assessment. Bull. Am. Meteorol. Soc. 79:19-38.

Herold, C., F. Mouton, O. Norbeck, and P.
Peduzzi. 2006. GNV-199-Preview global cyclone tracks datasets. Division of Early Warning and Assessment/Global and Regional Integrated Data, United Nations Environment Program, Geneva, http:// www.grid.unep.ch/activities/earlywarning/ preview/data/trop_cycl/trop_cycl.php.

Holland, G. J. 1983. Tropical cyclones in the Australian/Southwest Pacific region. Atmospheric Science Department, Colorado State University, Atmospheric Science Paper No. 363.

Hutchings, J. W. 1953. Tropical cyclones in the South west Pacific. N. Z. Geogr. 9:37-57.

International Research Institute for Climate and Society. 2006. Defining ENSO. The Earth Institute, Columbia University, http://iri.columbia.edu/climate/ENSO/ background/pastevent.html.

Joint Typhoon Warning Center. 2005. Tropical cyclone best track data site. U.S. Naval Pacific Meteorology and Oceanography Center, Pearl Harbor, https://metoc .npmoc.navy.mil/jtwc/best_tracks/index .html.

Kerr, I. S. 1976. Tropical storms and hurricanes in the Southwest Pacific, November 1939 to April 1969. New Zealand Meteorological Service, Wellington, Miscellaneous Publication 148.

Maunder, J. 1995. An historical overview regarding the intensity, tracks and frequency of tropical cyclones in the South Pacific during the last 100 years, and an analysis of any change in these factors. World Meteorological Organization, Geneva, Technical Document WMO/TD-No. 692/ Report No. TCP-37.

McGuire, B., I. Mason, and C. Kilburn. 2002. Natural hazards and environmental change. Arnold, London.

National Oceanic and Atmospheric Administration. 2007. Saffir-Simpson hurricane scale, http://www.aoml.noaa.gov/general/ lib/laescae.html.

Ramage, C. S., and A. M. Hori. 1981. Meteorological aspects of El Niño. Mon. Weather Rev. 109:1872-1835.

Revell, C. G. 1981. Tropical cyclones in the Southwest Pacific, November 1969 to 
April 1979. New Zealand Meteorological Service, Wellington, Miscellaneous Publication 170.

Revell, C. G., and S. W. Goulter. 1986. South Pacific tropical cyclones and the Southern Oscillation. Mon. Weather Rev. 114:1138-1145.

Salinger, J., J. Renwick, and S. Burgess. 2004. Tropical cyclone guidance. Island Clim. Update 50, http://www.niwa.cri.nz/ncc/ icu/2004-11/article.

Shaw, S. L. 1981. A history of tropical cyclones in the central North Pacific and the Hawaiian Islands, 1832-1979. National Oceanic and Atmospheric Administration, Silver Spring, Maryland, Report S/T 81-168.

Smith, K. 2004. Environmental hazards: Assessing risk and reducing disaster, 4th ed. Routledge, London.

Spennemann, D. H. R. 2004. Typhoons in Micronesia: The history of tropical cyclones and their effects until 1914. Division of Historic Preservation, Saipan, Commonwealth of the Northern Mariana Islands.

Sturman, A. P., and H. A. McGowan. 1999. Climate. Pages 3-18 in M. Rapaport, ed. The Pacific islands: Environment and society. Bess Press, Honolulu.

Sunderland, J. P., and A. Buzacott, eds. 1866. Mission life in the islands of the Pacific: Being a narrative of the life and labours of the Rev. A. Buzacott, missionary of Rarotonga, for some time co-worker with the Rev. John Williams, martyr of Erromanga. John Snow, London.

Syme-Buchanan, F. 1997. Islands devastated in the wake of Cyclone Martin. Pac. Islands Mon. December:11-12.

Terry, J. P., R. Raj, and R. A. Kostaschuk. 2001. Links between the Southern Oscillation Index and hydrological hazards on a tropical Pacific island. Pac. Sci. 55:275283.

Thompson, C. S. 1986a. The climate and weather of the Northern Cook Islands. New Zealand Meteorological Service,
Wellington, Miscellaneous Publication 188 (3).

Thompson, C. S. 1986b. The climate and weather of the Southern Cook Islands. New Zealand Meteorological Service, Wellington, Miscellaneous Publication 188 (2).

Thompson, C. S., S. Ready, and X. Zheng. 1992. Tropical cyclones in the Southwest Pacific: November 1979 to May 1989. National Institute of Water and Atmospheric Research/New Zealand Meteorological Service, Wellington.

Tobin, G. A., and B. E. Montz. 1997. Natural hazards: Explanation and integration. Guilford Press, New York.

Trenberth, K. E. 1997. The definition of El Niño. Bull. Am. Meteorol. Soc. 78:27712777.

U.S. Navy. 2004. Global tropical cyclone atlas v. 1.0. Fleet Numerical Meteorology and Oceanography Detachment, Asheville, North Carolina, http://navy.ncdc.noaa .gov/products/gtcca/gtccamain.html.

Visher, S. S. 1925. Tropical cyclones of the Pacific. Bernice P. Bishop Mus. Bull. 20.

Visher, S. S., and D. Hodge. 1925. Australian hurricanes and related storms, with an appendix on hurricanes in the South Pacific. Commonwealth Bureau of Meteorology, Melbourne, Bulletin No. 16.

Webster, P. J., G. J. Holland, J. A. Curry, and H.-R. Chang. 2005. Changes in tropical cyclone number, duration, and intensity in a warming environment. Science (Washington, D.C.) 309:1844-1846.

Williams, J. 1841. A narrative of missionary enterprises in the South Sea islands; with remarks upon the natural history of the islands, origin, languages, traditions, and usages of the inhabitants. John Snow, London.

Zillman, J. W. 1999. Opportunities and challenges for meteorological and hydrological warning systems. Pages 9-14 in Proceedings of the Australian Disaster Conference, 1-3 November 1999, Canberra. Emergency Management Australia, Dickson, Australian Capital Territory. 
